\title{
O FILTRO OCULTO DE REPERCUSSÃO GERAL: COMO O OBSCURECIMENTO DOS JUÍZOS DE RELEVÂNCIA CONTRIBUI PARA A CRISE DO STF
}

\section{THE COVERT FILTER OF GENERAL REPERCUSSION: HOW THE OBSCURENESS OF RELEVANCE-BASED JUDGMENTS CONTRIBUTES TO THE BRAZILIAN SUPREME COURT'S CRISIS}

\author{
Frederico Montedonio Rego \\ Juiz Federal Substituto. Mestrando em Direito pelo Centro Universitário de Brasília - \\ UniCEUB. Bacharel em Direito pela Universidade do Estado do Rio de Janeiro - UERJ. \\ E-mail: fmontedonio@gmail.com
}

Recebido em: 30/12/2016

Aprovado em: 13/03/2017

Doi: $10.5585 /$ rdb.v18i7.522

\begin{abstract}
RESUMO: O trabalho procura demonstrar que o Supremo Tribunal Federal utiliza uma espécie de "filtro oculto de relevância", pelo qual os Ministros da Corte rejeitam casos monocraticamente por não considerá-los importantes, embora sem admiti-lo de forma expressa e sem utilizar os mecanismos formais existentes para tal fim. Isto se dá basicamente por duas razões: (a) o entendimento de que a ausência de repercussão geral recai apenas sobre teses jurídicas, e não sobre casos concretos; e (b) o elevado quórum de dois terços para a negativa formal de repercussão geral. Assim, o Tribunal obscurece a distinção entre o juízo sobre o caráter jurídicoconstitucional das controvérsias e o juízo sobre a sua relevância. Isso gera inconsistências demonstráveis pela constatação de que várias matérias reiteradamente tidas como não constitucionais passam a ser vistas como constitucionais, ainda que sem alteração normativa, quando os Ministros, por alguma razão, começam a reputá-las relevantes. Tal forma de trabalho está na raiz da crise de funcionalidade da Corte: em verdade, ela sacrifica a transparência, a coerência e a qualidade das decisões do STF, além de torná-lo ainda mais assoberbado, já que tal sistemática acaba apenas por retroalimentar a litigiosidade, gerando incentivos e pretextos para a interposição incessante de recursos.

Palavras-chave: STF. Repercussão geral. Coerência. Transparência. Funcionalidade.
\end{abstract}

ABSTRACT: The study intends to demonstrate that the Brazilian Federal Supreme Court (STF) uses a kind of "covert relevance filter", by which the Justices, in individual decisions, reject cases because they are not considered important, although not openly admitting it, nor using the formal mechanisms designed for that purpose. This is due to two basic reasons: (a) the understanding that the lack of general repercussion refers to abstract legal questions, not concrete cases; and (b) the high quorum of two thirds to formally deny general repercussion. Thus, the Court obscures the distinction between the constitutional character of the dispute and its relevance. This generates inconsistencies demonstrable by the observation that several matters repeatedly considered as non constitutional turn out to be seen as constitutional, even without any normative changes, when the Justices, for some reason, begin to see them as relevant. That way of working lies at the root of the Court's functionality crisis: in reality, it sacrifices the transparency, the coherence and the quality of STF's decisions, making it even more overwhelmed, because this 
system ends up only feeding back litigation, generating incentives and pretexts to endless appealing.

Keywords: Brazilian Federal Supreme Court (STF). General repercussion. Coherence. Transparency. Functionality.

SUMÁRIO: Introdução; 1. O paradoxo da repercussão geral, ou "primeiro, o menos importante": um filtro de relevância somente utilizado de forma expressa em último caso; $1.1 \mathrm{As}$ desvantagens de um filtro que somente recai sobre teses abstratas; 1.1.1 A parcimônia no uso do filtro para não abdicar do poder de rever temas; 1.1.2 Os efeitos colaterais de um filtro exclusivo de teses: sobrestamento em massa com novas possibilidades de impugnação procesual; 1.1.3 A ineficácia de um filtro exclusivo de teses na atual realidade brasileira; 1.2 A fuga do quórum de dois terços para viabilizar decisões monocráticas; 2. O obscurecimento dos juízos de relevância como concausa da disfuncionalidade do Supremo Tribunal Federal; 2.1 A falta de clareza na distinção entre a relevância e a natureza constitucional do tema; $2.2 \mathrm{O}$ obscurecimento técnicomonocrático dos juízos de relevância como causa retroalimentadora da litigiosidade: uma produtividade frustrada; Conclusão; Referências Bibliográficas.

\section{INTRODUÇÃO}

Em 2015, passados quase dez anos do início do efetivo funcionamento da repercussão geral, o Supremo Tribunal Federal proferiu 116.628 decisões. Não há erro na digitação do número: a média foi de 10.602 decisões para cada um dos 11 Ministros, o que significa um ritmo de cerca de 30 decisões por dia para cada, durante todos os 365 dias do ano. No mesmo período, a Corte recebeu 93.476 processos novos - 16,93\% a mais do que no ano anterior -, que se somaram aos 56.230 então existentes no acervo. No balanço final, o Tribunal encerrou o ano com 53.890 feitos pendentes, já que cada caso pode ter mais de uma decisão e nem todas ocasionam a baixa de processos ${ }^{1}$. Em 28/9/2016, chegou-se à espantosa marca de um milhão de recursos extraordinários: o ARE 1.000.000, distribuído ao Min. Marco Aurélio, trata da revisão de uma gratificação referente aos Policiais Militares do Estado da Bahia.

Apenas a título de comparação, a Suprema Corte dos EUA recebe de 7.000 a 8.000 casos novos por ano, dos quais apenas 80 terão sustentações orais ouvidas e serão decididos pelo órgão plenário do tribunal ${ }^{2}$. Na Alemanha, o Tribunal Federal Constitucional recebe cerca de 6.000 novos casos por ano - o que é considerado uma "alta carga de trabalho" -, dos quais se entende que aproximadamente $99 \%$ (noventa e nove por cento) não possuem "significância constitucional fundamental"3. Restariam, portanto, cerca de 60 casos verdadeiramente importantes.

\footnotetext{
${ }^{1}$ BRASIL. Supremo Tribunal Federal. Relatório de atividades 2015. Brasília: Supremo Tribunal Federal, 2016. Disponível em: <http://www.stf.jus.br/arquivo/cms/sobreStfConhecaStfRelatorioAtividade/anexo/Relat_Ativ_STF2015.pdf>. Acesso em: 30 out.2016.

${ }^{2}$ Tradução livre do autor. No original: "Each Term, approximately 7,000-8,000 new cases are filed in the Supreme Court. (...) Plenary review, with oral arguments by attorneys, is currently granted in about 80 of those cases each Term, and the Court typically disposes of about 100 or more cases without plenary review" (ESTADOS UNIDOS DA AMÉRICA. Supreme Court. The Justices' Caseload. Disponível em: <https://www.supremecourt.gov/about/justicecaseload.aspx>. Acesso em: 30 out.2016.

${ }^{3}$ Tradução livre do autor. No original: "The workload of the Court is high. In particular, it receives more than 6,000 constitutional complaints every year. In order to deal with this high number of new proceedings, both Senates form three-member Chambers. These usually decide cases which have no fundamental constitutional significance approximately 99 per cent of proceedings." (ALEMANHA. Bundesverfassungsgerich. Court and Constitutional Organ. Disponível em: <http://www.bundesverfassungsgericht.de/EN/Das-Gericht/Gericht-undVerfassungsorgan/gericht-und-verfassungsorgan_node.html>. Acesso em: 30 out.2016.
} 
Um órgão jurisdicional de cúpula decide as questões jurídicas mais relevantes que se apresentam em cada país. Mas como definir o que é mais relevante ${ }^{4}$ ? Segundo critérios quantitativos, sobressaem-se as questões repetidas em maior número de processos. Critérios qualitativos apontariam para a gravidade da matéria de fundo, não importando a quantidade de processos: assim, uma questão de rara ocorrência prática, mas que envolvesse, e.g., um conflito entre direitos fundamentais, poderia ser tida como relevante. Critérios institucionais poderiam ressaltar a saliência de questões relacionadas ao pacto federativo e à separação de poderes. Critérios econômicos teriam em conta a magnitude dos impactos financeiros envolvidos na controvérsia. E assim por diante.

Parece evidente que um juízo sobre a relevância ou não de uma controvérsia envolve uma inevitável dose de discricionariedade, que é aceita e praticada em maior ou menor grau em vários países cujos tribunais de cúpula adotam filtros de relevância, tais como Estados Unidos, Alemanha, Argentina, Inglaterra, Canadá, Austrália e Japão ${ }^{5}$. No caso dos nossos vizinhos sulamericanos, a lei expressamente prevê que a Corte Suprema deve exercer uma "sã discricionariedade" na escolha de seus recursos extraordinários ${ }^{6}$. Sobre esse fenômeno mundial, afirma José Carlos Barbosa Moreira:

Em mais de um país tem-se feito sentir o problema do acúmulo de trabalho nas Cortes Supremas. O grande número de litígios que lhes chegam, sobretudo por via recursal, é fator importante de retardamento do desfecho dos pleitos. Ademais, a considerável variedade dos temas suscitados pode desviar a atenção dos juízes para assuntos menores, com prejuízo da respectiva concentração nas questões de mais relevância.

O fenômeno tem sido objeto de providências destinadas a limitar a quantidade de casos sujeitos ao julgamento das mencionadas Cortes. Quanto ao tipo de 'filtragem', o expediente preferido é o de confiar, no todo ou em parte, à própria

\footnotetext{
${ }^{4}$ Alguns autores defendem que não há discricionariedade na atribuição de repercussão geral, e que o instituto deve ser definido a partir do binômio "relevância e transcendência", que seriam conceitos jurídicos indeterminados (e.g., MARINONI, Luiz Guilherme; MITIDIERO, Daniel. Repercussão geral no recurso extraordinário. 2. ed. São Paulo: Revista dos Tribunais, 2008, p. 32-41). Sem colocar em dúvida a existência de tais elementos, é possível, no entanto, questionar se é possível preenchê-los de forma útil. Transcendência seria a qualidade do que se estende "para além do interesse subjetivo das partes na causa", o que, a rigor, se aplica a qualquer decisão do STF, pela sua simples posição como órgão de cúpula, cuja jurisprudência é observada e será invocada em outros casos. Quanto à relevância, seria composta de um "núcleo conceitual (certeza do que não é)" e de um "halo conceitual (dúvida do que pode ser)", mas nem sequer o núcleo de certeza negativa é definido. Cabe a advertência de que, quando se diz que tudo é relevante, nada pode ser realmente tratado como relevante, banalizando-se o significado do termo (ALVIM, Arruda. Repercussão geral: impressões e perspectivas. In: FUX, Luiz; FREIRE, Alexandre; DANTAS, Bruno (coords.). Repercussão geral da questão constitucional. Rio de Janeiro: Forense, 2014, p. 116). Este trabalho usa a expressão "relevância" em seu sentido comum, até por inexistência de acepção técnica: o que a lei faz, "para fins de repercussão geral", é apenas qualificar a relevância "do ponto de vista econômico, político, social ou jurídico" $\left(\mathrm{CPC} / 2015\right.$, art. $\left.1.035, \S 1^{\circ}\right)$. A relevância não é um atributo intrínseco de um tema, mas uma qualidade que pressupõe uma comparação: nada é relevante por si, e sim mais ou menos relevante que outra coisa, sob certo ponto de vista. $\mathrm{O}$ assunto será objeto de outro estudo.

${ }^{5}$ A propósito, v. DANTAS, Bruno. Repercussão geral. 3. ed. São Paulo: Revista dos Tribunais, 2012, p. 96-139; OLIVEIRA, Pedro Miranda de. Recurso extraordinário e o requisito da repercussão geral. São Paulo: Revista dos Tribunais, 2013, p. 273-278.

${ }^{6}$ É o que prevê, na Argentina, o art. 280 do Código de Processo Civil e Comercial da Nação (CPCN): "Quando a Corte Suprema conhecer do recurso extraordinário, a recepção da causa implicará a avocação dos autos. A Corte, segundo sua sã discricionariedade, e com a só invocação desta norma, poderá recusar o recurso extraordinário, por falta de lesão federal suficiente ou quando as questões discutidas resultarem insubstanciais ou carentes de transcendência" (destaques acrescentados). Tradução livre do autor; no original: "Cuando la Corte Suprema conociere por recurso extraordinario, la recepción de la causa implicará el llamamiento de autos. La Corte, según su sana discreción, y con la sola invocación de esta norma, podrá rechazar el recurso extraordinario, por falta de agravio federal suficiente o cuando las cuestiones planteadas resultaren insustanciales o carentes de trascendencia" (redação dada pela Lei n 23.774/1990).
}

Revista de Direito Brasileira | São Paulo, SP | v. 18 | n. 7 | p. 6 - 29 | Set./Dez. 2017 
Corte Suprema a incumbência de estabelecer o critério segundo o qual se hão de selecionar os recursos considerados merecedores de conhecimento e julgamento ${ }^{7}$.

A necessidade de um filtro de relevância também foi sentida no Brasil, devido ao assoberbamento do STF. Não se trata de um problema novo, tanto que é discutido pelos Ministros da Corte, pela comunidade jurídica e pela sociedade em geral desde as primeiras décadas do século passado ${ }^{8}$, e enfrentado também a partir de outras medidas ${ }^{9}$.

Nessa linha, valendo-se da competência prevista no art. 115, parágrafo único, alínea $c$, da Constituição de 1967, o Supremo Tribunal Federal criou a "arguição de relevância da questão federal", pela Emenda Regimental no 3/1975. À época, o recurso extraordinário destinava-se a assegurar tanto a observância da Constituição quanto a de tratados e leis federais (art. 114, III, da Constituição de 1967), e a arguição de relevância recaía apenas sobre as "questões federais", de modo que não se cogitava desse requisito no caso de ofensa à Constituição. $O$ instrumento foi objeto de diversas críticas, entre as quais a complexidade e onerosidade de seu procedimento, e o caráter secreto e não motivado das decisões ${ }^{10}$, além do estigma que foi associado ao instituto por ter sido criado durante o regime militar ${ }^{11}$. Criado o Superior Tribunal de Justiça, ao qual foi atribuída a guarda da legislação federal, e a redução do escopo do recurso extraordinário às questões constitucionais (arts. 102, III, e 105, III, da Constituição de 1988), entendeu-se que a arguição de relevância foi extinta em 7/4/1989, data da instalação do STJ (STF, ARv 14.159, Pleno, Rel. Min. Néri da Silveira, j. 27/4/1989).

Uma vez que o surgimento do STJ não foi capaz de desafogar o STF, encontrando-se hoje ambas as Cortes notoriamente sobrecarregadas, a ideia de um filtro de relevância retornou a partir do filtro da "repercussão geral", incluído no art. 102, $\S 3^{\circ}$, da Constituição pela Emenda Constitucional $n^{\circ} 45 / 2004$. Trata-se de instrumento pelo qual o STF pode "recusar" recursos extraordinários, desde que o faça pelo quórum qualificado de dois terços de seus membros: ou seja, pelo menos 8 de 11 Ministros.

$\mathrm{O}$ instituto foi regulamentado pela Lei $\mathrm{n}^{\circ}$ 11.418/2006, que introduziu os arts. 543-A e 543-B no CPC/1973. Tais normas não definiram "repercussão geral", mas apenas aludiram a conceitos vagos a serem "considerados" para tal fim, na seguinte fórmula aberta: "Para efeito da repercussão geral, será considerada a existência, ou não, de questões relevantes do ponto de vista econômico, político, social ou jurídico, que ultrapassem os interesses subjetivos da causa" (art. 543-A, $\S 1^{\circ}$ ). Entre outros preceitos, dispôs-se ainda o seguinte: (a) que a repercussão geral é requisito de conhecimento do recurso - anterior, assim, ao juízo de mérito -, sendo irrecorrível a decisão de negativa de repercussão (art. 543-A, caput); (b) que "[n]egada a existência da repercussão geral, a decisão valerá para todos os recursos sobre matéria idêntica" (art. 543-A, § $5^{\circ}$ ); e (c) "[q]uando houver multiplicidade de recursos com fundamento em idêntica controvérsia (...), [c]aberá ao Tribunal de origem selecionar um ou mais recursos representativos da

\footnotetext{
${ }^{7}$ MOREIRA, José Carlos Barbosa. Comentários ao Código de Processo Civil. Vol. V. 15. ed. Rio de Janeiro: Forense, 2010, p. 616-617.

${ }^{8}$ DANTAS, Bruno. Repercussão geral. 3. ed. São Paulo: Revista dos Tribunais, 2012, p. 84-89.

${ }^{9}$ Para uma análise dessas medidas, tais como a criação de óbices regimentais, o aumento do número de Ministros e a criação de jurisprudência vinculante, v. MANCUSO, Rodolfo de Camargo. Recurso extraordinário e recurso especial. 13. ed. São Paulo: Revista dos Tribunais, 2015, p. 86-110. Na mesma linha, v. OLIVEIRA, Pedro Miranda de. Recurso extraordinário e o requisito da repercussão geral. São Paulo: Revista dos Tribunais, 2013, p. 68-82.

${ }^{10}$ MANCUSO, Rodolfo de Camargo. Recurso extraordinário e recurso especial. 13. ed. São Paulo: Revista dos Tribunais, 2015, p. 87-88.

11 "[A] arguição de relevância veio a ser totalmente eliminada do sistema com a promulgação da Constituição de 1988. Diante da pecha de antidemocrático, o instituto sucumbiu à sede de mudança que guiava o constituinte de 1988. A ideia de que o produto dos vinte e um anos de ditadura militar deveria ser, tanto quanto possível, banido do cenário nacional foi determinante para o ocaso da argüição de relevância" (DANTAS, Bruno. Repercussão geral. 3. ed. São Paulo: Rev. dos Tribunais, 2012, p. 269).
} 
controvérsia e encaminhá-los ao Supremo Tribunal Federal, sobrestando os demais até o pronunciamento definitivo da Corte" (art. 543-B, caput e $\S 1^{\circ}$ ).

O mecanismo entrou em funcionamento com a Emenda Regimental n ${ }^{\circ} 21 / 2007$, do STF, que criou o Plenário Virtual, meio eletrônico para manifestação dos Ministros quanto à existência ou não de repercussão geral. Com a Emenda Regimental n ${ }^{\circ} 31 / 2009$, a votação no Plenário Virtual passou a se referir também à definição do caráter constitucional ou não da controvérsia, que antecede o juízo de repercussão geral. Até o final do $1^{\circ}$ semestre de 2016, 901 questões foram afetadas, tendo sido negada repercussão geral a 292 temas e reconhecida repercussão a outras 609 controvérsias, das quais 284 foram julgadas e 325 ainda estavam pendentes ${ }^{12}$. Inicialmente, os resultados foram vistos como animadores: houve grande redução do número de processos novos no Tribunal de 2007 a 2011, especialmente os de competência recursal extraordinária, que respondem pela maior parte da movimentação da Corte ${ }^{13}$. No entanto, a partir de 2012 o número de processos voltou a subir, como se vê abaixo ${ }^{14}$ :

\begin{tabular}{|c|c|c|}
\hline Ano & $\begin{array}{c}\text { Novos processos } \\
\text { protocolados no STF }\end{array}$ & $\begin{array}{c}\text { Número de julgamentos } \\
\text { (monocráticos + colegiados) }\end{array}$ \\
\hline $\begin{array}{c}\mathbf{2 0 1 6} \\
\left(\mathbf{1}^{\mathbf{c}} \text { semestre }\right)\end{array}$ & 52.618 & 61.484 \\
\hline $\mathbf{2 0 1 5}$ & 93.503 & 109.193 \\
\hline $\mathbf{2 0 1 4}$ & 79.943 & 107.964 \\
\hline $\mathbf{2 0 1 3}$ & 72.072 & 85.000 \\
\hline $\mathbf{2 0 1 2}$ & 72.148 & 84.039 \\
\hline $\mathbf{2 0 1 1}$ & 64.018 & 93.712 \\
\hline $\mathbf{2 0 1 0}$ & 71.670 & 98.529 \\
\hline $\mathbf{2 0 0 9}$ & 84.369 & 89.355 \\
\hline $\mathbf{2 0 0 8}$ & 100.781 & 104.237 \\
\hline $\mathbf{2 0 0 7}$ & 119.324 & 159.522 \\
\hline $\mathbf{2 0 0 6}$ & 127.535 & 110.284 \\
\hline
\end{tabular}

Caso o segundo semestre de 2016 seja igual ao primeiro, pode-se projetar que serão recebidos durante o ano 105.236 novos processos, e realizados 122.968 julgamentos, quantidades cada vez mais próximas ao período anterior ao da vigência da repercussão geral. E com um agravante que antes não havia: hoje há mais de 1,5 milhão de processos sobrestados nas instâncias de origem aguardando decisões a serem tomadas pelo STF em processos afetados ao

12 BRASIL, Supremo Tribunal Federal. Repercussão geral: estatísticas e relatórios. Disponível em: <http://www.stf.jus.br/portal/cms/verTexto.asp?servico=jurisprudenciaRepercussaoGeral\&pagina=listas_rg >.

Acesso em: 31 jul.2016.

${ }^{13}$ Os processos de competência recursal extraordinária correspondem às seguintes classes: recurso extraordinário (RE), agravo de instrumento (AI - utilizado até a Lei $\mathrm{n}^{\circ}$ 12.322/2010) e agravo em recurso extraordinário (ARE utilizado a partir da Lei $\mathrm{n}^{\circ}$ 12.322/2010). A repercussão geral é pertinente apenas para essas classes (CF, art. 102, III), e não para os feitos de competência originária (CF, art. 102, I) ou recursal ordinária (CF, art. 102, II). Em 2006, antes da implantação da repercussão geral, os processos de competência recursal extraordinária representaram 95,27\% de todos os feitos distribuídos. Esse percentual começou a cair em 2007, chegando a 76,41\% em 2009. Depois voltou a subir, chegando a 84,71\% em 2014 (BRASIL. Supremo Tribunal Federal. Porcentagem de RE, AI e ARE em relação aos processos distribuídos - 1990 a 2014 . Disponível em: $<$ http://www.stf.jus.br/portal/cms/verTexto.asp?servico=estatistica\&pagina=REAIProcessoDistribuidoAnosAnterior es>. Acesso em: 14 set.2016.

14 BRASIL. Supremo Tribunal Federal. Movimento processual a partir de 1940. Disponível em: <http://www.stf.jus.br/portal/cms/verTexto.asp?servico=estatistica\&pagina=movimentoProcessual $>$. Acesso em 30 jul.2016. 
regime da repercussão geral $^{15}$, processos esses que, na sistemática anterior à criação do filtro, estariam tramitando. E, considerando que as decisões de mérito em repercussão geral até então impactaram "apenas" 89.338 processos nas instâncias de origem ${ }^{16}$, o saldo é amplamente negativo.

A sistemática da repercussão geral parece apenas ter transferido o problema de lugar e produzido uma sensação de alívio ilusória: se por algum tempo houve diminuição do ingresso de novos processos no STF, efeito que praticamente já se esvaiu, vê-se que esses processos somente não subiram à Corte Suprema porque ficaram sobrestados nos tribunais de origem (CPC/1973, art. 543-B, $\left.\S 1^{\circ}\right)^{17}$. Isso tende a ser agravado com o novo $\mathrm{CPC}$, que, diante do reconhecimento de uma repercussão geral, impõe a suspensão "de todos os processos pendentes, individuais ou coletivos, que versem sobre a questão e tramitem no território nacional" (CPC/2015, art. 1.037, II), e não apenas dos recursos extraordinários (CPC/1973, art. 543-B, $\left.\S 1^{\circ}\right)$. Vale dizer, a paralisação atingirá todos os processos em todos os graus de jurisdição, independentemente da fase em que se encontrem, caso tratem da mesma questão.

Tais dados apontam para o fracasso da repercussão geral, ao menos enquanto filtro recursal e medida de racionalização dos trabalhos do Supremo Tribunal Federal. Em quase dez anos de funcionamento, o mecanismo produziu somente uma atenuação passageira no número de novos processos que chegam à Corte, e apenas porque eles estão suspensos sine die nas instâncias de origem, às centenas de milhares, em prejuízo do direito dos jurisdicionados à razoável duração do processo (CF, art. $5^{\circ}$, LXXVIII).

Além disso, trata-se de um filtro de relevância que não tem impedido a chegada de cerca de 100 mil processos por ano ao STF, nem poupado a Corte de ter de proferir aproximadamente o mesmo número de decisões em idêntico período. Afetadas 901 questões à repercussão geral de 2007 até meados de 2016 - número que contrasta com a cifra aproximada de um milhão de decisões proferidas nesse intervalo -, vê-se que o STF continua decidindo sobre temas irrelevantes. Temas sobre os quais a Corte não deveria se debruçar, já que a repercussão geral é condição para conhecer do recurso extraordinário.

Desnecessário notar que, natural e obviamente, o STF não está a decidir 100 mil casos relevantes por ano: "[q]uando tudo é tratado como importante... nada é"18. Se ainda assim o Tribunal se obriga a decidir cada um desses processos, está empregando o seu escasso tempo em casos que não podem ser considerados mais importantes do ponto de vista geral. A não ser que essas dezenas de milhares de decisões recusassem, justamente por falta de relevância, a análise da maior parte das controvérsias trazidas ao conhecimento da Corte, como acontece na Alemanha e nos Estados Unidos. Não é isso, porém, o que ocorre no Brasil. Ou, melhor dizendo, não é o que ocorre expressamente.

\footnotetext{
${ }^{15}$ BRASIL. Supremo Tribunal Federal. Processos sobrestados em razão da repercussão geral. Disponível em: <http://www.stf.jus.br/portal/cms/verTexto.asp?servico=estatistica\&pagina=sobrestadosrg>. Acesso em: 30 out. 2016.

16 BRASIL. Supremo Tribunal Federal. Impacto da repercussão geral. Disponível em: <http://www.stf.jus.br/portal/cms/verTexto.asp?servico=estatistica\&pagina=impactorg>. Acesso em: 30 out. 2016

${ }^{17}$ Nesse sentido: "Da forma que está, como afirma Humberto Theodoro Júnior, não há uma redução significativa no número de questões discutidas no STF, mas somente um benefício de 'represar' os recursos nos Tribunais de origem até que o recurso extraordinário paradigma e com repercussão geral reconhecida tenha o seu julgamento de mérito" (MEDINA, José Miguel Garcia; GUIMARÃES, Rafael de Oliveira; FREIRE, Alexandre. Da repercussão geral: evolução e críticas ao instituto. In: FUX, Luiz; FREIRE, Alexandre; DANTAS, Bruno (coords.). Repercussão geral da questão constitucional. Rio de Janeiro: Forense, 2014, p. 372-373).

${ }^{18}$ GOMES JUNIOR, Luiz Manoel; GAJARDONI, Fernando da Fonseca. Anotações sobre a repercussão geral nos recursos extraordinário e especial. In: FUX, Luiz; FREIRE, Alexandre; DANTAS, Bruno (coords.). Repercussão geral da questão constitucional. Rio de Janeiro: Forense, 2014, p. 443.
} 
Sem aprofundar aqui o debate doutrinário sobre se a repercussão geral é ou não um filtro discricionário $^{19}$, este trabalho quer apenas demonstrar que hoje está em pleno funcionamento uma espécie de "filtro oculto" de relevância, pelo qual a Corte rejeita casos por não considerá-los importantes, embora sem admiti-lo de forma expressa e sem utilizar os mecanismos formais existentes para tal fim. As razões para evitar a utilização formal do filtro da repercussão geral são basicamente duas, como será exposto no capítulo II: (a) o entendimento de que a ausência de repercussão recai apenas sobre teses jurídicas, e não sobre casos concretos; e (b) o elevado quórum de dois terços para a negativa de repercussão geral.

Expostas as causas, o estudo segue para demonstrar, no capítulo III, como o STF utiliza um "filtro oculto" de repercussão geral, contornando aquelas características de modo a exercer juízos de irrelevância de forma monocrática e restrita ao caso concreto. Isso pode ser evidenciado pela constatação de que várias controvérsias que chegam à Corte são objeto de reiteradas decisões ao longo dos anos que assentam o seu caráter infraconstitucional ou meramente fático, de modo que o recurso não é conhecido e as decisões recorridas são mantidas. No entanto, muitas vezes de forma súbita e sem que nenhuma mudança normativa tenha ocorrido, quando a Corte passa a entender que o tema é de algum modo relevante, a mesma matéria começa a ser reputada como constitucional, de modo que o recurso é conhecido e a decisão recorrida revista. $\mathrm{Na}$ sequência, pretende-se demonstrar que esta forma de trabalho está na raiz da crise de funcionalidade da Corte: em verdade, ela sacrifica a transparência, a coerência e a qualidade das decisões do STF, além de torná-lo ainda mais assoberbado, já que tal sistemática acaba apenas por retroalimentar a litigiosidade.

Não deixa de ser paradoxal constatar que a repercussão geral, tal como praticada hoje pelo Supremo Tribunal Federal, é um filtro de relevância somente utilizado de forma expressa em último caso, invertendo uma conhecida máxima de gestão do tempo: "primeiro, o mais importante". A seguir, será demonstrado por que e como isso ocorre.

\section{O PARADOXO DA REPERCUSSÃO GERAL, OU "PRIMEIRO, O MENOS IMPORTANTE": UM FILTRO DE RELEVÂNCIA SOMENTE UTILIZADO DE FORMA EXPRESSA EM ÚLTIMO CASO}

$\mathrm{O}$ art. 323 do RI/STF prevê que "Quando não for caso de inadmissibilidade do recurso por outra razão, o(a) Relator(a) ou o Presidente submeterá, por meio eletrônico, aos demais Ministros, cópia de sua manifestação sobre a existência, ou não, de repercussão geral". São essas "outras razões" - e não a falta de repercussão geral - que normalmente são invocadas para inadmitir recursos, razões essas comumente identificadas com óbices antigos e recorrentemente erguidos pela jurisprudência da Corte ao acolhimento das pretensões dos recorrentes. São basicamente duas as razões para que esse tipo de solução defensiva seja tida como preferencial: as desvantagens de um filtro que recai apenas sobre teses abstratas, e não sobre casos concretos (item II.1), e o elevado quórum de dois terços (item II.2).

\subsection{As desvantagens de um filtro que somente recai sobre teses abstratas}

Diante da opinião geral favorável à instituição da repercussão geral - afinal, quase ninguém diria que o STF deve julgar causas de reduzida importância -, pouco se fala das desvantagens decorrentes de uma das características do mecanismo, tal como praticado hoje: a de

19 Apenas a título exemplificativo, em defesa do caráter político - e não jurisdicional - da análise quanto à repercussão geral, v. ALVIM, Arruda. Repercussão geral: impressões e perspectivas. In: FUX, Luiz; FREIRE, Alexandre; DANTAS, Bruno (coords.). Repercussão geral da questão constitucional. Rio de Janeiro: Forense, 2014, p. 110, 113-115. Para uma defesa de que o juízo não é discricionário, v. DANTAS, Bruno. Repercussão geral. 3. ed. São Paulo: Revista dos Tribunais, 2012, p. 274-282.

Revista de Direito Brasileira | São Paulo, SP | v. 18 | n. 7 | p. 6 - 29 | Set./Dez. 2017 
que ele recai apenas sobre teses abstratas, e não sobre casos concretos. Como parte da reação às críticas sofridas pela antiga arguição de relevância, e em atenção a um ideal de isonomia, entende-se hoje que a Corte não nega repercussão geral a casos particulares, mas às teses jurídicas neles discutidas, o que projeta efeitos sobre todos os processos semelhantes. É o que vem sendo chamado em doutrina de "objetivação do recurso extraordinário"20.

Essa característica do filtro da repercussão geral o torna potencialmente indesejado por três razões: (a) uma vez usado, impede, na prática, que a Corte volte a ser provocada sobre o assunto, o que implica abdicação do poder de revisitar o tema (item II.1.1); (b) gera efeitos colaterais por implicar sobrestamentos em massa e abrir novas vias de impugnação processual (item II.1.2); e (c) é ineficaz para conter o acesso ao STF (item II.1.3). Veja-se.

\subsubsection{A parcimônia no uso do filtro para não abdicar do poder de rever temas}

Quando a Corte nega repercussão geral a uma tese, ela abre mão de decidir sobre aquele assunto não apenas no caso concreto, mas em todos os casos semelhantes, e de forma definitiva. Embora teoricamente haja a possibilidade de revisão da tese $\left(C P C / 2015\right.$, art. $927, \S \S 2^{\circ}$ a $4^{\circ}$, e RI/STF, art. 103), na prática o juízo de ausência de repercussão geral impede que o Tribunal volte a ser provocado sobre aquele mesmo assunto em futuros recursos extraordinários, já que não cabe sequer agravo da decisão que inadmite recurso extraordinário por falta de repercussão geral $^{21}$. Essa já era a jurisprudência da Corte na vigência do CPC/1973 (Pleno, AI 760.358-QO, Rel. Min. Gilmar Mendes, j. 19/11/2009), que veio a ser confirmada no art. 1.042 do CPC/2015.

Ocorre que a relevância de um assunto pode variar ao longo do tempo. A alteração das circunstâncias pode tornar relevante determinada controvérsia que antes não despertava interesse, e vice-versa. A consideração de aspectos relativos ao momento em que surge um problema, ou no qual se deve dedicar atenção a ele, é aceita em diversos países que utilizam filtros de relevância. Considere-se, por exemplo, o que já decidiu a Suprema Corte dos EUA:

"Petições podem ter sido negadas porque, embora sérias questões constitucionais tenham sido levantadas, pareceu a pelo menos seis membros da Corte que a matéria ou não estava madura, ou era moribunda para merecer jurisdição; que seria melhor a questão aguardar a perspectiva do tempo, ou que o tempo iria em breve enterrar a questão, ou, por uma ou outra razão, era melhor esperar e ver; ou que a matéria constitucional estava ligada a matérias não constitucionais que levantaram dúvidas sobre a possibilidade de que a matéria constitucional pudesse efetivamente ser isolada; ou por várias outras razões não relacionadas ao mérito" 22 .

\footnotetext{
${ }^{20}$ OLIVEIRA, Pedro Miranda de. Recurso extraordinário e o requisito da repercussão geral. São Paulo: Revista dos Tribunais, 2013, p. 375-377.

${ }^{21}$ Um caso raro de revisão da tese ocorreu no RE 614.232 AgR-QO-RG, Rel. Min. Ellen Gracie, j. 20/10/2010, em que se reviu a negativa de repercussão geral do tema discutido no RE 592.211, Rel. Min. Menezes Direito, j. $7 / 11 / 2008$. Isto só ocorreu porque o Tribunal de origem admitiu o recurso extraordinário, apesar de o STF já ter negado repercussão geral ao tema, o que permitiu à Corte Suprema decidir novamente o assunto. Veja-se que a revisão não se deu porque tivesse ocorrido mudança na Constituição ou na lei, mas sim com base numa avaliação da relevância das consequências de uma declaração incidental de inconstitucionalidade, formalmente feita pela instância de origem, numa matéria que o STF já havia entendido infraconstitucional. Sobre o entrelaçamento da relevância ou irrelevância com o caráter constitucional ou infraconstitucional da controvérsia, v. o item III.1 deste trabalho, abaixo. 22 ESTADOS UNIDOS DA AMÉRICA. Supreme Court. Darr v. Burford, 339 U.S. 200 (1950). Tradução livre do autor. No original: "Petitions may have been denied because, even though serious constitutional questions were raised, it seemed to at least six members of the Court that the issue was either not ripe enough or too moribund for adjudication; that the question had better await the perspective of time, or that time would soon bury the question, or, for one reason or another, it was desirable to wait and see; or that the constitutional issue was entangled with nonconstitutional issues that raised doubt whether the constitutional issue could be effectively isolated; or for various other reasons not relating to the merits".
}

Revista de Direito Brasileira | São Paulo, SP | v. 18 | n. 7 | p. 6 - 29 |Set./Dez. 2017 
O mesmo ocorre quando a Corte reconhece a repercussão geral e decide a controvérsia constitucional. A diferença é que aqui há uma decisão de mérito, mas a vocação de perenidade do julgamento é a mesma, pois, por idênticas razões, não é viável voltar a provocar a Corte para rediscutir aquele assunto em novos recursos extraordinários, salvo em casos patológicos de descumprimento assumido da orientação do STF (CPC/2015, art. 1.041). Considerando que a relevância de um tema pode variar ao longo do tempo, essa característica do filtro explica, em parte, a parcimônia na sua utilização: é uma forma de a Corte não abdicar definitivamente do poder de revisitar o assunto, em outras circunstâncias. Essa parcimônia explica, também em parte, a discrepância entre o número de temas afetados (901) e o de decisões proferidas pela Corte (aproximadamente um milhão) desde a Emenda Regimental no 21/2007, que inaugurou o efetivo funcionamento da repercussão geral, até meados de 2016.

Mas não se trata apenas de uma questão de manutenção de poder: o filtro de repercussão geral, tal como hoje praticado, gera efeitos colaterais, como se verá abaixo.

\subsubsection{Os efeitos colaterais de um filtro exclusivo de teses: sobrestamento em massa com novas possibilidades de impugnação procesual}

Além disso, um filtro exclusivamente baseado em teses causa um sobrestamento em massa dos processos que discutem os temas afetados, abrindo toda uma nova via de possíveis impugnações processuais para questionar a correção do enquadramento de casos concretos às teses já selecionadas para discussão. Uma vez classificado um caso concreto como abrangido por uma questão de repercussão geral afetada pelo STF, surge para a parte prejudicada, seja pela suspensão do processo, seja pela decisão de mérito desfavorável, a pretensão de apontar particularidades do caso concreto que o diferenciem da controvérsia em tese, o que gera incidentes tanto nas instâncias de origem como no Supremo Tribunal Federal.

Na vigência do CPC/1973, o Supremo Tribunal Federal foi provocado inúmeras vezes, por diversas vias processuais, sob a alegação de que casos concretos não se enquadravam a teses afetadas à repercussão geral. Assim é que se formou a jurisprudência de que o enquadramento feito pelas instâncias de origem não pode ser questionado no STF por via de reclamação, agravo de instrumento, agravo em recurso extraordinário e mandado de segurança, cabendo apenas agravo interno para o próprio Tribunal de origem (Rcls 7.547 e 7.569, Rel. Min. Ellen Gracie, $\mathrm{j}$. 19/11/2009; AI 760.358-QO, Rel. Min. Gilmar Mendes, j. 19/11/2009; MS 29.009 AgR, Rel. Min. Cármen Lúcia, j. 2/3/2011).

O CPC/2015 procurou manter essa sistemática, mas admitiu o cabimento de reclamação ao STF sob a alegação de aplicação indevida da tese com repercussão geral reconhecida, bem como de não aplicação aos casos que a ela correspondam, desde que esgotadas as instâncias ordinárias (art. 988, IV, $\S \S 4^{\circ}$ e $5^{\circ}$, II). Além disso, previu várias formas de impugnar a aplicação da sistemática da repercussão geral na origem.

No novo Código de Processo Civil, quando se trata de tese já afetada, mas ainda não decidida, a Presidência ou Vice-Presidência dos Tribunais de origem deve sobrestar os recursos extraordinários pendentes sobre o mesmo tema (CPC/2015, art. 1.030, III). A parte prejudicada pode interpor agravo interno dessa decisão para o próprio Tribunal $\left(\mathrm{CPC} / 2015\right.$, art. $\left.1.030, \S 2^{\circ}\right)$, de modo a demonstrar a distinção do seu caso.

Já o relator do processo no Supremo Tribunal Federal “determinará a suspensão do processamento de todos os processos pendentes, individuais ou coletivos, que versem sobre a questão e tramitem no território nacional" (CPC/2015, art. 1.035, § 5 $)$. Ampliou-se assim a suspensão prevista no $\mathrm{CPC} / 1973$, que somente recaía sobre os recursos extraordinários pendentes (CPC/1973, art. 543-B, $\S 1^{\circ}$ ) e podia ser estendida para outros casos, a critério do relator (RI/STF, art. 328, caput). Isso deve aumentar ainda mais o número de processos sobrestados 
aguardando decisões da Suprema Corte, que hoje é de cerca de 1,5 milhão, potencializando os efeitos colaterais do filtro da repercussão geral. O STF, no entanto, ainda não decidiu se este é um efeito automático da decisão de afetação, se depende ou não de manifestação do relator, se repercute sobre os temas já afetados antes da entrada em vigor do CPC/2015 e se atinge inclusive os processos de competência originária do STF: essas questões foram discutidas pelo Plenário da Corte no julgamento da ACO 1.870 AgR-ED, Rel. Min. Dias Toffoli, j. 1\%/7/2016, sem que se tenha chegado a uma conclusão sobre o assunto.

De toda sorte, determinado o sobrestamento, a parte recorrida pode se insurgir contra tal medida se o recurso for intempestivo, cabendo agravo da decisão $\left(\mathrm{CPC} / 2015\right.$, art. 1.035 , $\S 6^{\circ} \mathrm{e}$ $7^{\circ}$ ). O próprio Tribunal de origem pode selecionar recursos representativos e sugerir a afetação ao STF, sobrestando todos os processos sobre o mesmo tema na sua jurisdição territorial $\left(\mathrm{CPC} / 2015\right.$, art $\left.1.036, \S 1^{\circ}\right)$. A parte recorrida, por sua vez, pode interpor agravo interno da decisão de sobrestamento se o recurso for intempestivo $\left(\mathrm{CPC} / 2015\right.$, art. $1.036, \S \S 2^{\circ}$ e $\left.3^{\circ}\right)$. E, afetada uma tese pelo STF, em se tratando de controvérsia repetitiva, a parte que se sentir prejudicada pode se insurgir demonstrando as particularidades de seu caso concreto, em requerimento dirigido ao juiz ou relator da instância em que estiver o processo, cabendo agravo de instrumento ou interno, conforme o caso (CPC/2015, arts. 1.037, §§ $9^{\circ}$ a 13).

Todas essas possibilidades de impugnação processual decorrentes da afetação de teses ao regime da repercussão geral desfavorecem a utilização formal e expressa do filtro de relevância, sobretudo agora com as normas que preveem a suspensão de todos os processos pendentes $\left(\mathrm{CPC} / 2015\right.$, art. $\left.1.035, \S 5^{\circ}\right)$, e o cabimento de reclamação para o STF (CPC/2015, art. 988, IV, $\S \S 4^{\circ}$ e $5^{\circ}$, II), de modo que o debate sobre a correção do enquadramento do caso concreto à tese não poderá ser inteiramente contido na origem.

E não é só: além desses efeitos colaterais, um filtro cujo objeto recai exclusivamente sobre teses não é capaz de conter a avalanche de processos que todos os anos chegam, em volume cada vez maior, ao Supremo Tribunal Federal. Isto se dá pelas razões a seguir.

\subsubsection{A ineficácia de um filtro exclusivo de teses na atual realidade brasileira}

Um filtro de teses é uma boa ideia, com potencial para solucionar centenas ou milhares de processos com uma única decisão. Ao se referir a essa qualidade do mecanismo da repercussão geral, afirma Taís Schilling Ferraz:

"Este novo instrumento processual insere no controle difuso de constitucionalidade componente de natureza objetiva, capaz de evitar infindáveis decisões sobre um mesmo tema pela Corte Constitucional. É que, uma vez definido que o assunto versado em recurso determinado tem relevância, sob algum dos aspectos legais, será levado a julgamento de mérito pelo Plenário do STF, e o resultado que daí advier orientará as decisões judiciais futuras em todos os processos que tragam a mesma discussão, nas instâncias recursais ordinárias ou especiais. Ensejará a retratação de decisões contrárias à orientação do STF ou tornará prejudicados os recursos que desafiem decisões conformes"23.

Nada a opor, portanto, à existência de um filtro de teses. O problema é a restrição do objeto do filtro a teses, o que o torna incapaz de conter a demanda junto ao Supremo Tribunal Federal. Basta lembrar que o Judiciário terminou o ano de 2015 com quase 74 milhões de

\footnotetext{
${ }^{23}$ FERRAZ, Taís Schilling. Repercussão geral - muito mais que um pressuposto de admissibilidade. In: PAULSEN, Leandro (coord.). Repercussão geral no recurso extraordinário: estudos em homenagem à Ministra Ellen Gracie. Porto Alegre: Livraria do Advogado, 2011, p. 80.
} 
processos pendentes ${ }^{24}$. Todos esses casos, ao menos teoricamente, podem chegar ao Supremo Tribunal Federal. Quantas teses são discutidas em 74 milhões de processos? Quantas teriam de ser classificadas e ter a repercussão geral negada para reduzir a demanda de novos processos sobre o Supremo Tribunal Federal?

Esse descomunal número de processos torna insuficientes todos os esforços de contenção da demanda sobre o STF a partir de um filtro que recaia apenas sobre teses. Filtra-se uma tese, surgem outras dez, cem, mil, todas potencialmente reconduzíveis à Constituição de 1988, devido ao seu caráter analítico. E, mesmo quanto à tese filtrada, sempre será possível demonstrar que os casos concretos têm especificidades que escapam ao que foi decidido, implicando a necessidade de um novo exame particular. Imagens mitológicas, como o trabalho de Sísifo, ou mais prosaicas, como o ato de "enxugar gelo", exprimem bem o que se quer demonstrar. Não se conseguiu até hoje, nem se conseguirá, reduzir a demanda sobre o Supremo Tribunal Federal filtrando apenas teses abstratas.

Tendo isso em conta, a solução que tem sido preferencialmente adotada pelo STF é, na aparência, mais simples, rápida e sem efeitos colaterais: decisões monocráticas que, além de tudo, não se submetem ao quórum de dois terços. Contornar esse quórum é a segunda razão para evitar o uso do filtro da repercussão geral, como se expõe a seguir.

\subsection{A fuga do quórum de dois terços para viabilizar decisões monocráticas}

A segunda razão que leva o Tribunal a evitar o uso expresso do filtro de relevância é o elevado quórum de dois terços, ou 8 de 11 Ministros, para negar a repercussão geral, a tornar preferenciais as soluções que podem ser adotadas monocraticamente ${ }^{25}$. Fora os casos de erros grosseiros, é praxe o STF negar seguimento a recursos por qualificar a matéria controvertida como infraconstitucional, e não constitucional (Súmulas 280 e 636), ou como fática, e não jurídica (Súmula 279), ou apontar a falta de prequestionamento (Súmulas 282 e 356$)^{26}$. A propósito, foi exatamente o que ocorreu com o ARE 1.000.000, em que o Min. Marco Aurélio, em decisão monocrática de 4/10/2016, aplicou as Súmulas 279 e 280. Todas essas alternativas podem ser adotadas de forma singular pelo relator, cabendo agravo para a respectiva Turma, um colegiado de cinco Ministros, e não para o Plenário. Como regra geral, esse agravo confirmará a decisão monocrática, por julgamento em lista: um mecanismo sumário em que não há debate, e no qual centenas de casos podem ser julgados por vez.

Como se sabe, a "monocratização" do STF é um fenômeno preexistente à repercussão geral, explicando-se como forma de o Tribunal lidar com a maior parte do volume. Segundo

${ }^{24}$ BRASIL, Conselho Nacional de Justiça. Relatório “Justiça em Números 2016: ano-base 2015”. Brasília: CNJ, 2016, p. $\quad 42 . \quad$ Disponível em: <http://www.cnj.jus.br/files/conteudo/arquivo/2016/10/b8f46be3dbbff344931a933579915488.pdf >. Acesso em 30 out.2016.

25 “[O] elevado quórum tornou por demais onerosa a recusa do recurso por ausência de repercussão geral, o que foi constatado nos resultados da aplicação do instituto no STF, na contramão do que se pretendia: desafogamento do tribunal do elevado número de processos (restrição procedimental)" (MEDINA, Damares. A repercussão geral no Supremo Tribunal Federal. São Paulo: Saraiva, 2016, e-book, posição 71-72).

26 "A invocação da falta de prequestionamento e dos mais variados defeitos formais nos recursos, bem como o confinamento de diversas questões suscitadas ao plano infraconstitucional ou ao plano da matéria fática transformaram-se nos grandes escudos da Corte, na tentativa de viabilizar seu funcionamento frente à avalanche de causas que aportavam no protocolo. Situações de fato e de direito idênticas acabavam solucionadas de formas diversas, quando questões absolutamente circunstanciais, como prequestionamento e requisitos formais as distinguissem para fins de acesso à decisão final pelo STF." (FERRAZ, Taís Schilling. A amplitude dos efeitos das decisões sobre questão constitucional de repercussão geral: critérios para aplicação de precedentes no direito brasileiro. Porto Alegre, 2015, p. 40. Dissertação de mestrado em direito aprovada na PUC/RS. Texto em PDF. Disponível em: <http://biblioteca.trf4.jus.br/diap/teses/FERRAZ_TA\%C3\%8DS_SCHILLING.pdf>. Acesso em 30 out.2016. 
levantamento do projeto "Supremo em Números", da FGV Direito Rio, de todas as decisões do STF entre 1992 e 2013, 93\% foram monocráticas ${ }^{27}$. Porém, mesmo com a criação de uma sistemática colegiada de relevância, a solução monocrática ainda é a preferencial ${ }^{28}$. Nesse sentido, não se confirmou a previsão de que "o instituto reforçará a atuação colegiada paradigmática da Corte" 29 . A tabela a seguir comprova que, mesmo sob o funcionamento da repercussão geral, a Corte ainda atua de forma esmagadoramente monocrática ${ }^{30}$ :

\begin{tabular}{|c|c|c|c|c|c|c|c|}
\hline Tipo de decisão & $\mathbf{2 0 1 0}$ & $\mathbf{2 0 1 1}$ & $\mathbf{2 0 1 2}$ & $\mathbf{2 0 1 3}$ & $\mathbf{2 0 1 4}$ & $\mathbf{2 0 1 5}$ & $\begin{array}{c}\mathbf{2 0 1 6} \\
\left(\mathbf{1}^{\mathbf{}} \text { sem }\right)\end{array}$ \\
\hline Colegiada & 11.333 & 13.096 & 12.088 & 14.106 & 17.070 & 17.752 & 7.826 \\
\hline Monocrática & 98.354 & 89.311 & 77.770 & 76.147 & 97.371 & 98.917 & 56.666 \\
\hline Não informado & 1 & 13 & 216 & & & & \\
\hline Soma: & $\mathbf{1 0 9 . 6 8 8}$ & $\mathbf{1 0 2 . 4 2 0}$ & $\mathbf{9 0 . 0 7 4}$ & $\mathbf{9 0 . 2 5 3}$ & $\mathbf{1 1 4 . 4 4 1}$ & $\mathbf{1 1 6 . 6 6 9}$ & $\mathbf{6 4 . 4 9 2}$ \\
\hline
\end{tabular}

Essas são as causas pelas quais a repercussão geral é, na prática atual do STF, um filtro de relevância só utilizado expressamente em último caso. A seguir, mostra-se que as decisões monocráticas, confirmadas pelas Turmas sempre que preciso, são um modo de exercer juízos de relevância sem passar pelo quórum de dois terços, e com efeitos restritos ao caso concreto, sem repercutir abstratamente sobre todas as teses discutidas no recurso e sobre todos os processos semelhantes. Em outras palavras: se o uso formal da sistemática da repercussão geral é dificultoso e produz uma série de efeitos colaterais, basta, como regra, não a utilizar formalmente, mantendo a praxe das decisões monocráticas. Porém, a alternativa encontrada também não é isenta de problemas: em verdade, o atual modelo de trabalho do STF está na raiz de sua crise de funcionalidade, como se procurará demonstrar.

\section{O OBSCURECIMENTO DOS JUÍZOS DE RELEVÂNCIA COMO CONCAUSA DA DISFUNCIONALIDADE DO SUPREMO TRIBUNAL FEDERAL}

Como visto acima, a crise do STF não é um fenômeno novo, nem pode ser atribuído a alguns poucos fatores. Certamente o grande rol de competências do art. 102 da Constituição contribui para a sobrecarga da Corte, ao incluir ações penais em face de um grande número de autoridades com prerrogativa de foro, mandados de segurança de atos do TCU, pedidos de extradição etc. O que o presente capítulo pretende demonstrar é que a atual forma de trabalho do Tribunal nos processos de competência recursal extraordinária - que, em 2014, representavam

27 HARTMANN, Ivan; FERREIRA, Lívia da Silva. Ao relator, tudo: o impacto do aumento do poder do Ministro relator no Supremo. In: Revista Opinião Jurídica, Fortaleza, ano 13, n. 17, p. 274. Disponível em: <http://periodicos.unichristus.edu.br/index.php/opiniaojuridica/article/view/266/179>. Acesso em: 30 out.2016.

${ }^{28} \mathrm{O}$ caráter habitual do exercício monocrático do poder decisório no STF pode levar à conclusão de que não faz sentido criar filtros colegiados. É o que se extrai da seguinte passagem: "O art. 557 do Código de Processo Civil [de 1973] autorizava até o mais - julgamento do mérito do recurso -, agora, em sede de recurso extraordinário, um pressuposto processual não poderá ser julgado com fundamento em tal dispositivo, mas o mérito recursal sim! Tratase de uma verdadeira contradição: o relator pode julgar o mérito do recurso, provendo-o ou não, mas não poderá, monocraticamente, decidir se está presente o pressuposto da repercussão geral, salvo quando já houver precedente sobre o tema" (GOMES JUNIOR, Luiz Manoel; GAJARDONI, Fernando da Fonseca. Anotações sobre a repercussão geral nos recursos extraordinário e especial. In: FUX, Luiz; FREIRE, Alexandre; DANTAS, Bruno (coords.). Repercussão geral da questão constitucional. Rio de Janeiro: Forense, 2014, p. 462 - destaques no original).

${ }^{29}$ DANTAS, Bruno. Repercussão geral. 3. ed. São Paulo: Revista dos Tribunais, 2012, p. 317.

30 BRASIL. Supremo Tribunal Federal. Estatísticas do STF: decisões. Disponível em: <http://www.stf.jus.br/portal/cms/verTexto.asp?servico=estatistica\&pagina=decisoesgeral>. Acesso em 30 jul. 2016.

Revista de Direito Brasileira | São Paulo, SP | v. 18 | n. 7 | p. 6 - 29 |Set./Dez. 2017 
$84,71 \%$ do volume total de processos (v. nota 13 , acima) - tem um importante papel enquanto concausa da disfuncionalidade da Corte. Isto ocorre porque o exercício de um "filtro oculto" de relevância, de forma monocrática e restrita ao caso concreto, e caracterizado pela falta de clareza na distinção entre a relevância e a natureza constitucional da controvérsia (item III.1), acaba por gerar inconsistências na jurisprudência do Tribunal, retroalimentando a litigiosidade ao gerar incentivos e pretextos para a interposição de cada vez mais recursos (item III.2). Ambas as ideias são desenvolvidas a seguir.

\subsection{A falta de clareza na distinção entre a relevância e a natureza constitucional do tema}

Há muito a doutrina denuncia a obscuridade dos critérios usados pelo Supremo Tribunal Federal para determinar se uma controvérsia tem caráter constitucional ou não, o que se opera a partir da jurisprudência segundo a qual a ofensa constitucional que autoriza um recurso extraordinário deve ser "direta", e não "indireta" ou "reflexa". Essa obscuridade, agravada pelo caráter analítico da Constituição de 1988, serve como meio de defesa do Tribunal ante o grande volume de processos. Como afirma Bruno Dantas:

"Em última análise, e sem perder de vista a jurisprudência da Corte, não nos parece exagerado afirmar que a teoria da ofensa direta tem servido convenientemente aos interesses do STF de impedir que o número insuportável de recursos aumente ainda mais.

Como os conceitos de ofensa direta ou reflexa não estão bem delineados na doutrina ou na jurisprudência, o tribunal serve-se dessa contingência para manejar sua pauta, visualizando ofensas diretas e reflexas sem um padrão definido que assegure às partes a necessária previsibilidade" 31 .

Com o advento da repercussão geral, essa indefinição na distinção entre o que é constitucional ou não passou a se projetar também sobre o que é ou não relevante, mesclando-se os conceitos. Um exemplo é oportuno para ilustrar o argumento.

Durante muitos anos, discutiu-se no Judiciário a chamada "incorporação dos quintos", isto é, saber se os servidores públicos teriam ou não direito a somar à sua remuneração a quinta parte do valor correspondente às gratificações por funções comissionadas exercidas entre a vigência da Lei $n^{\circ}$ 9.624/1998 e a Medida Provisória $n^{\circ}$ 2.225-45/2001. A jurisprudência consolidada era no sentido da possibilidade de incorporação. A Fazenda Pública entendia que essa incorporação não tinha amparo legal, e buscava reverter condenações por meio de recursos extraordinários que invocavam, entre outros argumentos, o de violação ao princípio da legalidade. Tais recursos eram negados porque a controvérsia era classificada como infraconstitucional, inclusive com invocação da Súmula 636/STF, segundo a qual "Não cabe recurso extraordinário por contrariedade ao princípio constitucional da legalidade, quando a sua verificação pressuponha rever a interpretação dada a normas infraconstitucionais pela decisão recorrida" (e.g., AI 725.112 AgR, 1ª T., Rel. Min. Cármen Lúcia, j. 26/5/2009; RE 544.856 AgR, $1^{a}$ T., Rel. Min. Dias Toffoli, j. 20/3/2012). Esse entendimento foi reproduzido em centenas de decisões monocráticas e colegiadas. O Superior Tribunal de Justiça afirmou o direito em recurso repetitivo (REsp 1.261.020, 1 ${ }^{a}$ S., Rel. Min. Mauro Campbell Marques, j. 24/10/2012), e vários tribunais até implementaram administrativamente a incorporação dos quintos a seus servidores.

\footnotetext{
${ }^{31}$ DANTAS, Bruno. Repercussão geral. 3. ed. São Paulo: Revista dos Tribunais, 2012, p. 183. Reconhecendo o caráter "problemático" da distinção entre ofensas constitucionais diretas e indiretas, e apontando a sistemática da repercussão geral como "solução para o dilema entre o acesso irrestrito à jurisdição constitucional e a imposição de limites artificiais”, v. BARROSO, Luís Roberto. O controle de constitucionalidade no direito brasileiro. 7 . ed. São Paulo: Saraiva, 2016, p. 136-138. Em sentido semelhante, OLIVEIRA, Pedro Miranda de. Recurso extraordinário e o requisito da repercussão geral. São Paulo: Revista dos Tribunais, 2013, p. 118.
} 
Eis que, no RE 638.115, Rel. Min. Gilmar Mendes, j. 19/3/2015, submetido ao regime da repercussão geral, a maioria dos Ministros decidiu rever o tema para, ao final, não apenas assentar o caráter constitucional da controvérsia, como negar o direito à incorporação, justamente por violação ao princípio constitucional da legalidade. $\mathrm{O}$ que interessa para o presente estudo não é propriamente o mérito do direito à incorporação, mas como e por que razões o Tribunal decidiu alterar a forma de entender a questão, destacando-se, a propósito, as manifestações de alguns juízes da Corte.

Mantiveram-se fieis ao entendimento de que a questão seria infraconstitucional os Ministros Rosa Weber, Luiz Fux, Cármen Lúcia e Celso de Mello. O relator, Min. Gilmar Mendes, defendeu que decisões judiciais que violam grosseiramente a lei acabam por violar a própria Constituição. Sem discordar da premissa, o Min. Luiz Fux replicou que não se poderia falar de violação grosseira por parte de centenas de decisões mantidas pelo STF. O Min. Teori Zavascki apontou o caráter delicado da distinção entre questões constitucionais e infraconstitucionais, mas acompanhou o relator por uma razão pragmática: não gerar uma distinção entre a decisão do recurso extraordinário e a de dois mandados de segurança que discutiam a mesma questão e constavam da mesma pauta; o Tribunal entraria no mérito da questão de qualquer forma, já que em mandado de segurança não se exige repercussão geral. $\mathrm{O}$ Min. Dias Toffoli afirmou que o STJ é que seria a última instância se o STF não pudesse reverter suas decisões, e lembrou outras hipóteses em que uma matéria tradicionalmente considerada infraconstitucional passou a ser reputada constitucional. Por fim, o Min. Ricardo Lewandowski reviu seu entendimento anterior e reconheceu a repercussão geral do tema, ao sublinhar o caráter discricionário desse juízo e o impacto financeiro envolvido.

Seria a justificativa do Min. Ricardo Lewandowski a mais transparente, ao assumir expressamente preocupações de natureza consequencialista e a natureza discricionária do filtro? A linha jurisprudencial anterior, ao considerar a discussão infraconstitucional, não estaria na verdade dizendo que a matéria até então não era tida como relevante, embora sem assumi-lo expressamente? É possível responder afirmativamente a ambas as questões. Outro exemplo reforça o ponto e mostra que não se trata de caso isolado.

Algo semelhante ocorreu na discussão do alegado direito retroativo dos servidores do Poder Judiciário do Estado do Rio de Janeiro ao índice de $24 \%$, decorrente de extensão judicial do aumento previsto na Lei Estadual $\mathrm{n}^{\circ} 1.206 / 1987$, que só contemplava os servidores do Executivo e do Legislativo. O Tribunal de Justiça local deu ganho de causa aos servidores, editando inclusive uma súmula para uniformizar sua jurisprudência. Os recursos extraordinários interpostos pelo Estado alegavam, em síntese, violação à Súmula 339/STF e à Súmula Vinculante 37, segundo as quais "Não cabe ao Poder Judiciário, que não tem função legislativa, aumentar vencimentos de servidores públicos sob fundamento de isonomia". No entanto, segundo a jurisprudência do STF, esse entendimento só se aplica a reajustes, e não a revisões gerais, que podem ser estendidas pelo Judiciário (Pleno, RE 584.313 QO-RG, Rel. Min. Gilmar Mendes, j. 6/10/2010). Assim, em dezenas de decisões monocráticas, confirmadas por ambas as Turmas, praticamente todos os Ministros entenderam que a controvérsia em exame tinha natureza infraconstitucional, pois seria necessário interpretar a Lei $\mathrm{n}^{\circ}$ 1.206/1987 para saber se ela previa um reajuste ou uma revisão geral (e.g., $1^{\mathrm{a}} \mathrm{T}$, ARE 838.535 AgR, Rel. Min. Rosa Weber; $2^{\mathrm{a}}$ T., ARE 810.579 AgR, Rel. Min. Teori Zavascki).

A Procuradoria-Geral do Estado do Rio de Janeiro empenhou-se em expor o impacto financeiro do tema para os cofres públicos, já que o entendimento do tribunal de origem beneficiava retroativamente milhares de servidores ativos e inativos. Até que, a partir de votovista do Min. Gilmar Mendes no ARE 841.799 AgR, Rel. Min. Teori Zavascki, j. 23/2/2016, no qual houve análise detalhada da legislação infraconstitucional aplicável, concluiu-se que se tratava de reajuste, e não de revisão geral. Assim, a $2^{\text {a }}$ Turma passou a dar provimento aos recursos do Estado, ao entender que a posição firmada pelo TJRJ era contrária à Constituição. 
Afetada a controvérsia ao Plenário Virtual (ARE 909.437, Rel. Min. Luís Roberto Barroso, j. 1\%/2016), o relator assim destacou a relevância do tema: "o acréscimo de $24 \%$ (vinte e quatro por cento) aos rendimentos e proventos dos milhares de servidores ativos e aposentados do Poder Judiciário do Estado do Rio de Janeiro, retroativo a pelo menos cinco anos antes do ajuizamento de cada ação individual, é capaz de produzir um impacto financeiro bilionário às já combalidas finanças do Estado, cuja situação calamitosa é notória". Ao final, dez Ministros reconheceram o caráter constitucional e a repercussão geral da matéria, e, por 8 votos a 2, reafirmaram a jurisprudência da Corte para dar provimento ao recurso do Estado, vencidos os Ministros Marco Aurélio e Luiz Fux. Não se manifestou a Min. Rosa Weber.

Os exemplos se multiplicam e a brevidade do presente estudo não é compatível com a análise de outros casos, o que será objeto de outro trabalho. O que se quer demonstrar é que a discussão sobre o caráter constitucional ou infraconstitucional de uma controvérsia - que é, ou deveria ser, uma questão técnica - é obscurecida pela relevância ou irrelevância que o Tribunal atribui ao tema, aferida segundo critérios político-discricionários, e, sobretudo, pelo resultado que se pretende obter: caso se queira desprover o recurso, a matéria é tida como infraconstitucional; caso se pretenda provê-lo, o tema é visto como constitucional. No entanto, sem mudança da Constituição, uma matéria reiteradamente entendida como infraconstitucional não passa a ser subitamente constitucional. Se isto ocorre, possivelmente existem considerações de ordem não estritamente técnica envolvidas nessas definições. O problema, porém, não reside propriamente na existência desse tipo de considerações, que são até certo ponto inevitáveis, mas no seu obscurecimento. Trata-se, em suma, de um "mecanismo informal de seletividade recursal no STF”, como afirma Damares Medina:

"Dados da atividade jurisdicional do STF indicam que dentre todos os processos distribuídos no STF entre 2007 e 2013, aproximadamente $80 \%$ foram decididos monocraticamente.

Esse cenário sugere outra realidade, subjacente ao modelo normativo da jurisdição constitucional brasileira, na qual o Supremo teria uma ampla discricionariedade na escolha daquilo que efetivamente julga (decisão colegiada e dialógica).

O diagnóstico de que o STF não tem o controle de sua pauta e de que seria relativamente fácil acessar o tribunal merece ser revisitado, especialmente porque ancorado de forma exclusiva em análises quantitativas dos recursos autuados no tribunal, sem investigar os rumos e destinos efetivamente dados a essa massa recursal (fulcrado no dogma de que o juiz não pode deixar de decidir).

Nesse sentido, Verissimo já observara a existência de mecanismos informais de seletividade recursal no STF, no exercício do controle incidental de constitucionalidade no STF, cunhando a expressão 'certiorari à brasileira'.

Essa escolha do que julgar (em contraposição ao que é cartorariamente decidido) é operacionalizada monocraticamente pelos ministros do STF, por intermédio dos filtros recursais, nos quais se aplica a jurisprudência defensiva do tribunal.

(...) Decerto, a necessidade de dar uma resposta jurisdicional a centenas de milhares de recursos anuais deu azo ao surgimento de mecanismos informais de seletividade recursal, na dinâmica decisória do STF. (...)

(...) O perfil preponderantemente monocrático da atividade jurisdicional do STF sugere mais uma operacionalidade da seletividade do tribunal (no legítimo exercício ao direito de escolha do que é possível julgar), que o distanciamento entre a práxis jurisdicional do tribunal e o seu modelo normativo constitucional. 
Isso porque incumbe ao STF o controle do cumprimento de uma constituição analítica e eclética de 250 artigos, 97 disposições transitórias, mais 88 emendas constitucionais" 32

Marcos Paulo Verissimo já cogitava da existência de "juízos materiais de irrelevância" exercidos por decisões monocráticas antes mesmo da EC n ${ }^{\circ} 45 / 2004$. Veja-se:

“É verdade que pode haver também, por trás dessas decisões monocráticas, uma espécie de certiorari informal, isto é, de filtro informal destinado a tornar viável a gestão de casos nas turmas e no plenário. Nesse sentido, não se pode saber se já não estaria sendo praticado informalmente, no tribunal, antes mesmo da Emenda Constitucional n. 45.04, um juízo prévio de relevância dos casos relativos a recursos extraordinários, juízo esse justificado formalmente sob o prisma formal-procedimental da admissibilidade (nesse sentido, decisões de indeferimento liminar fundadas na falta de requisitos formais ou materiais de admissibilidade poderiam estar travestindo, já de algum tempo, juízos materiais de irrelevância, somente autorizados a partir da EC 45). Essa é uma conjectura que pode fazer especial sentido quando se tem em conta a rigidez com que o STF foi construindo ao longo do tempo suas exigências formais e materiais de admissibilidade do recurso extraordinário (por exemplo, quanto às últimas, no que diz respeito ao prequestionamento, ou à noção de interpretação razoável, contida na Súmula 400, ou a todas as matérias tratadas nas Súmulas 283, 284, 356 e 636, entre outras. No entanto, a inexistência de qualquer pesquisa metodologicamente consistente apontando essa tendência com clareza impedenos de tratar essa suposição como qualquer coisa além de pura conjectura"33.

Passados quase dez anos do efetivo funcionamento da repercussão geral, vários dados parecem confirmar a conjectura. É o caso da constatação de que apenas $5 \%$ de todos os recursos de natureza extraordinária (AI, ARE e RE) decididos monocraticamente foram providos pelo Supremo Tribunal Federal entre 2007 e 2013, enquanto que, nos temas com repercussão geral julgados no mesmo período, houve provimento em $38 \%$ dos $\operatorname{casos}^{34}$. Isso sugere que a Corte mantém monocraticamente $95 \%$ das decisões que lhe são submetidas não por considerá-las corretas, mas por não reputá-las suficientemente relevantes para um reexame. Tanto que, nas matérias relevantes, o índice de provimento é bastante superior.

A ideia de um "juízo oculto de relevância" foi claramente enunciada pelo Min. Gilmar Mendes no julgamento do RE 377.457 ED, em 19/10/2016, em que S. Exa. assentou:

"Se a gente examinar - e a toda hora isso ocorre -, inclusive agora na repercussão geral, essas escapadelas que nós damos e, na matéria infra, temos que ter até mais cuidado, como dizemos a 'ofensa reflexa', no fundo, é um juízo de relevância. Às vezes, nós estamos concordando com o caso; às vezes, nós estamos... Em suma, diante da massa de casos que chegam aos gabinetes, isto

\footnotetext{
${ }^{32}$ MEDINA, Damares. A repercussão geral no Supremo Tribunal Federal. São Paulo: Saraiva, 2016, e-book, posições 83-85. No mesmo sentido: "Sempre nos pareceu ser extremamente saudável que houvesse um filtro para os recursos endereçados aos Tribunais Superiores. Estes filtros, que existem em muitos outros países, são uma forma de seleção muito mais razoável do que a nossa conhecida e criticável jurisprudência defensiva. (...) Além do mais, a jurisprudência 'defensiva' já significa, hoje, um certiorari de facto" (WAMBIER, Teresa Arruda Alvim; WAMBIER, Luiz Rodrigues. Repercussão geral: como transformá-la num instituto adequado à magnitude da missão de uma Corte Superior? In: FUX, Luiz; FREIRE, Alexandre; DANTAS, Bruno (coords.). Repercussão geral da questão constitucional. Rio de Janeiro: Forense, 2014, p. 621 - destaques no original).

${ }^{33}$ VERISSIMO, Marcos Paulo. A Constituição de 1988, vinte anos depois: Suprema Corte e ativismo judicial "à brasileira”. In: Revista Direito GV, São Paulo. 4(2), jul.-dez. 2008, p. 420-421.

${ }^{34}$ MEDINA, Damares. A repercussão geral no Supremo Tribunal Federal. São Paulo: Saraiva, 2016, e-book, posição 93-94.
}

Revista de Direito Brasileira | São Paulo, SP | v. 18 | n. 7 | p. 6 - 29 |Set./Dez. 2017 
vai se fazendo. Toda hora, isso ocorre, infelizmente. E o ideal é que se reduzam os números de processos para que, de fato, isso seja mais consistente. Mas todos nós, vamos dizer de maneira muito clara, acabamos dizendo: 'Não, essa matéria é infra', às vezes, ou 'ofensa reflexa'. No momento seguinte, a matéria ganha densidade e a gente acaba discutindo em Plenário. Certamente, todos vamos ter exemplos disso. (...) Porque, no fundo, também vamos reconhecer... Quer dizer, conseguir que o recurso extraordinário passe em todas as peneiras para chegar ao conhecimento, essa é uma dificuldade. É um pouco uma batalha, como a do espermatozoide, não é? Aquela coisa realmente dificílima" ${ }^{35}$ (destaques acrescentados)

A falta de clareza na distinção entre a relevância e a natureza constitucional do tema pode ser ainda demonstrada pelo entrelaçamento entre ambos os conceitos na prática do STF. As deliberações do Plenário Virtual mostram que a decisão quanto ao caráter constitucional ou não da questão está amalgamada ao juízo quanto à existência ou não de repercussão geral. Nada impede que se negue repercussão geral a uma questão constitucional, mas na imensa maioria dos casos não é o que acontece. É o que demonstra Damares Medina, cuja análise se estende da Emenda Regimental $n^{\circ} 31 / 2009$, que inaugurou a deliberação no Plenário Virtual quanto ao caráter constitucional ou não do tema, até 31/12/2013. Diz a autora:

"No universo de 510 temas que tiveram a questão constitucional apreciada no plenário virtual, em 348 ela foi reconhecida e em apenas dois destes tiveram a sua repercussão geral negada (Temas 175 e 681). Em todos os 162 temas em que a questão constitucional foi negada, a repercussão geral também foi negada.

Conclui-se que há uma correlação positiva entre a questão constitucional e a repercussão geral" 36 .

Assim, no Plenário Virtual, quando se considera o tema constitucional, quase sempre se reconhece a repercussão geral; quando se nega repercussão geral a um tema, via de regra ele também é tido como infraconstitucional. Esta última hipótese gera um problema lógico, pois se a controvérsia é infraconstitucional, a rigor não se precisaria deliberar sobre a existência ou não de repercussão geral, que só se refere a matérias constitucionais $\left(\mathrm{CF} \text {, art. } 102, \S 3^{\circ}\right)^{37}$. No entanto, essa sistemática passou a ser adotada a partir do RE 584.608, Rel. Min. Ellen Gracie, j. 4/12/2008, e só se explica como forma de atribuir ao tema os efeitos transcendentes da falta de repercussão geral, impedindo a subida de novos processos sobre o assunto, na forma do art. 324 , $\S 2^{\circ}$, do RI/STF ${ }^{38}$.

35 Transcrição feita pelo autor do voto do Min. Gilmar Mendes na sessão plenária de 19/10/2016, disponível em https://www.youtube.com/watch?v=yPjPELOR1qw\&feature=youtu.be, acesso em 30 out.2016 (9m05s a 10m27s).

${ }_{36}$ MEDINA, Damares. A repercussão geral no Supremo Tribunal Federal. São Paulo: Saraiva, 2016, e-book, posição 88 .

${ }^{37}$ Nesse sentido: “A hipótese, na verdade, não é de falta de repercussão geral, pois a matéria não é constitucional, segundo o próprio STF. O caso é de descabimento do recurso extraordinário, pura e simplesmente. Essa análise é, inclusive, anterior à que se faz sobre a existência de repercussão geral. Se a questão discutida no recurso extraordinário não é constitucional, nem há que se indagar sobre se ela tem ou não repercussão geral. (...) Essa incompreensão do STF certamente decorre de uma preocupação de ordem prática. Deparando-se com diversos recursos extraordinários incabíveis (por veicularem questão infraconstitucional, p. ex.) e repetitivos, o STF houve por bem resolver a sua admissibilidade pela técnica da repercussão geral, de modo a que a respectiva decisão fosse considerada vinculante para os tribunais inferiores, que deixariam, por isso, de remeter ao STF recursos extraordinários interpostos naqueles termos" (DIDIER JR., Fredie; CUNHA, Leonardo Carneiro da. Curso de direito processual civil. Vol. 3. 13. ed. Salvador: Juspodivm, 2016, p. 372).

${ }^{38}$ Bruno Dantas parece não ter captado o sentido do dispositivo, como se vê da seguinte passagem: "Aliás, embora esteja topograficamente em dispositivo referente ao exame da repercussão geral, o conteúdo do $\S 2^{\circ}$ do art. 324 do RISTF trata de julgamento eletrônico de juízo de admissibilidade, que deveria ser realizado monocraticamente pelo relator e, eventualmente, desafiado por agravo interno. Ao que parece, a regra em comento consiste em artifício para 
Trata-se, porém, de um procedimento que gera perplexidades. No RE 946.648, Rel. Min. Marco Aurélio, j. 30/6/2016, seis Ministros entenderam que a matéria era infraconstitucional e sem repercussão geral, enquanto outros cinco se manifestaram no sentido de que se trataria de controvérsia constitucional e com repercussão geral (o que comprova mais uma vez que os conceitos estão mesclados). Como a maioria absoluta se manifestou pelo caráter infraconstitucional, a rigor estaria prejudicada a deliberação quanto à repercussão geral da "questão constitucional", para a qual o art. 102, § $3^{\circ}$, da Constituição exige quórum de dois terços $^{39}$. No entanto, como no Plenário Virtual ambas as votações são simultâneas, e o art. 324, § $2^{\circ}$, do RI/STF exige quórum de dois terços para negar repercussão geral mesmo a matérias infraconstitucionais, a proclamação automática do resultado foi pelo reconhecimento do caráter constitucional e da repercussão geral do tema, vencidos seis Ministros. Há impugnações pendentes e ainda não analisadas quanto a essa proclamação do resultado. De toda forma, esse caso deixa claro o atrelamento entre o caráter constitucional ou infraconstitucional da controvérsia e a presença ou ausência de repercussão geral, respectivamente, bem como as perplexidades geradas pela forma de trabalho do STF.

Em hipótese semelhante (ARE 702.780, reautuado como RE 729.884, Rel. Min. Dias Toffoli, j. 27/9/2012), houve seis votos pelo caráter infraconstitucional da controvérsia que debate a possibilidade ou não de impor à Fazenda Pública o ônus de liquidar sentença contra si proferida. No entanto, a repercussão geral foi reconhecida, tendo votado nesse sentido apenas dois Ministros, sendo as três abstenções somadas a tais votos. Quando do julgamento de mérito, porém, a Corte decidiu não conhecer do recurso com base na votação ocorrida no Plenário Virtual, em que a maioria absoluta entendia não haver matéria constitucional. Talvez tenha contribuído para isso - de forma um tanto paradoxal - o fato de que foi pautada para a mesma sessão a ADPF 219, Rel. Min. Marco Aurélio, em que se discutia exatamente a mesma questão. O julgamento da ADPF iniciou-se e foi suspenso por pedido de vista. Mas é curioso constatar que a mesma controvérsia foi recusada, em recurso extraordinário, por ser reputada infraconstitucional, enquanto paralelamente é julgada numa ADPF, cujo parâmetro de cabimento é ainda mais restrito: não basta de se tratar de matéria constitucional, sendo necessário que se alegue violação a "preceito fundamental". É mais uma prova da inconsistência dos critérios e da seletividade informal adotada pelo STF: aqui, o não conhecimento do recurso extraordinário serviu como meio de economia processual, tendo em vista que a questão já seria debatida nos autos da ADPF.

Com o CPC/2015, a tradicional nebulosidade na fronteira entre o que é constitucional e infraconstitucional não poderá mais servir de pretexto para a extinção sumária de processos, já que os arts. 1.032 e 1.033 preveem o dever de conversão do recurso especial em extraordinário, e vice-versa. Tenta-se acabar com uma hipótese que gerava perplexidade, na qual o STJ não conhecia do recurso especial por entender que a matéria era constitucional, e o STF não conhecia do recurso extraordinário por entender que a mesma matéria seria infraconstitucional. $O s$ dispositivos reconhecem a falta de clareza da jurisprudência ao definir o caráter constitucional

evitar tanto a interposição do agravo interno contra a decisão individual do relator quanto o seu julgamento em sessão presencial" (DANTAS, Bruno. Repercussão geral. 3. ed. São Paulo: Revista dos Tribunais, 2012, p. 307).

39 Já houve casos em que se negou a repercussão geral por seis votos, sendo quatro expressos e duas abstenções, por se entender que se tratava de matéria infraconstitucional (AI 841.047, Rel. Min. Cezar Peluso, j. 27.05.2011; RE 633.843, Rel. Min. Cezar Peluso, j. 27.05.2011). Tais decisões foram consideradas "bizarras" por Luciano Felicio Fuck (Repercussão geral: desenvolvimento e desafios. In: FUX, Luiz; FREIRE, Alexandre; DANTAS, Bruno (coords.). Repercussão geral da questão constitucional. Rio de Janeiro: Forense, 2014, p. 393). Com a redação dada ao art. 324, $\S 2^{\circ}$, do RI/STF pela Emenda Regimental no 47/2012, passou-se a exigir o quórum de dois terços para negar a repercussão geral mesmo em se tratando de matéria infraconstitucional. A rigor, porém, não haveria que se deliberar sobre a falta de repercussão geral de matérias infraconstitucionais, muito menos por dois terços. Como visto acima, trata-se de uma solução adotada por razões eminentemente pragmáticas. 
ou não de uma controvérsia, privilegiando a solução de mérito pela Corte que, afinal, o STF considerar competente (o STJ ou o próprio STF).

No entanto, embora concebidos para fazer frente à alta demanda numérica de decisões do STF, todos esses mecanismos informais de seletividade recursal operacionalizados principalmente por meio de decisões monocráticas em verdade se frustram, porque acabam retroalimentando a litigiosidade, como se expõe a seguir.

\subsection{O obscurecimento técnico-monocrático dos juízos de relevância como causa retroalimentadora da litigiosidade: uma produtividade frustrada}

Como visto, em vez de utilizar formalmente o Plenário Virtual para negar repercussão geral aos casos que não considera relevantes, assumindo assim o exercício de um juízo de relevância, a Corte prefere se valer de outros obstáculos de natureza pretensamente técnica, que dispensam o quórum de dois terços e supostamente produzem o mesmo resultado, sem os efeitos colaterais do filtro de teses. No entanto, a utilização desses obstáculos demanda um tempo de análise processual muito superior ao que exigiria um filtro inicial assumidamente baseado na relevância: hoje, por mais irrelevantes que sejam as discussões "do ponto de vista econômico, político, social ou jurídico" $\left(\mathrm{CPC} / 2015\right.$, art. 1.035, $\left.\S 1^{\circ}\right)$, é preciso tempo para se debruçar sobre elas e compreender os fundamentos do acórdão recorrido, as teses do recurso extraordinário, as contrarrazões e a decisão de admissibilidade, tudo a fim de aferir se a controvérsia "irrelevante" é fática, infraconstitucional, não está prequestionada etc.

Quando se recebem dezenas de milhares de processos todos os anos e se tem de proferir ainda mais decisões para dar conta da demanda, o tempo de análise exigido para cada processo determina se o Tribunal cumpre bem ou não o seu papel institucional, além de ser um fator crucial para a decisão das partes de recorrer ou não ao STF, bem como de provocar ou não incidentes dentro da própria Corte. A análise baseada em obstáculos técnicos, ao contrário do que pode parecer, cria um incentivo e um pretexto para impugnações pela parte que está a perder a causa, retroalimentando a litigiosidade.

O incentivo é a maior demora exigida por tal análise de natureza pretensamente técnica, em comparação com o tempo que seria demandado por um filtro inicial de relevância: assim, apenas por retardar significativamente o trânsito em julgado de uma decisão desfavorável, podese dizer que o recurso cumpriu a sua função e foi bem-sucedido, independentemente do resultado. Quanto maior a demora gerada pelo recurso para tornar definitiva uma conclusão desfavorável, maior o incentivo para recorrer.

O pretexto é precisamente o obstáculo técnico invocado: uma decisão monocrática segundo a qual a matéria discutida tem natureza infraconstitucional é o pretexto para o agravo interno da parte que vai alegar o caráter constitucional da discussão. Como regra geral, esse agravo confirmará a decisão monocrática, por julgamento em lista (sumário e sem debates). A decisão do agravo fornece o pretexto para a parte insistir na natureza constitucional da discussão, opondo primeiros embargos de declaração, segundos embargos de declaração, embargos de divergência, embargos de declaração em embargos de divergência etc. Não se quer aqui discutir quem tem razão, se a parte ou o Tribunal, mas sim a lógica da discussão: não faz sentido ter um debate sempre baseado em obstáculos de natureza técnica quando se tem um filtro de relevância que, se utilizado de forma prioritária e assumida, poderia gerar uma decisão bem mais rápida e irrecorrível (CPC/2015, art. 1.035, caput), eliminando o incentivo e o pretexto para os recursos e produzindo uma jurisdição mais transparente.

O CPC/2015 ajuda a tornar a relevância o critério preferencial, tirando o suporte da jurisprudência defensiva ao dispor que "O Supremo Tribunal Federal ou o Superior Tribunal de 
Justiça poderá desconsiderar vício formal de recurso tempestivo ${ }^{40}$ ou determinar sua correção, desde que não o repute grave" (art. $1.029, \S 3^{\circ}$ ). Perde relevo, assim, o argumento pragmático de que "não faria sentido analisar-se o preenchimento ou não da repercussão geral, movimentando a máquina do Supremo Tribunal Federal para uma análise política, quase meritória, da questão constitucional subsumida no recurso, se fosse ele, por exemplo, deserto em virtude da insuficiência de preparo"41. Mesmo antes do CPC/2015, o STF já relevou um problema com o preparo do recurso em razão da relevância do tema, ao qual foi atribuída repercussão geral: "saber se o ensino domiciliar (homeschooling) pode ser proibido pelo Estado ou viabilizado como meio lícito de cumprimento, pela família, do dever de prover educação, tal como previsto no art. 205 da CRFB/1988” (RE 888.815, Rel. Min. Luís Roberto Barroso, j. 4/6/2015). O novo dispositivo deixa claro que o critério primordial é a relevância: portanto, o filtro da repercussão geral deve ser o primeiro a ser aplicado, não o último. Do contrário, o Tribunal passará a maior parte do seu tempo decidindo casos irrelevantes.

Ganhou força, portanto, a posição defendida pelo Min. Gilmar Mendes no ARE 663.637 AgR-QO, Rel. Min. Ayres Britto, j. 12.09.2012, no sentido de que "a flexibilização dos requisitos de admissibilidade do recurso extraordinário é imperativo lógico da sistemática da repercussão geral, a partir da análise de relevância do tema". Veja-se que o sobrestamento de recursos sobre temas com repercussão geral reconhecida é feito nas instâncias de origem antes do juízo de admissibilidade (RI/STF, art. 328-A $)^{42}$, justamente porque esse juízo poderia resultar na inadmissão do recurso segundo os critérios da jurisprudência defensiva não expressamente relacionados à relevância (ofensa indireta, matéria fática, falta de prequestionamento etc.). Isso acabaria por gerar a interposição de um agravo em recurso extraordinário, que não poderia deixar de ser encaminhado ao STF, por não estar expressamente baseado numa negativa de repercussão geral $\left(\mathrm{CPC} / 1973\right.$, art. 544; CPC/2015, art. 1.042) ${ }^{43}$. Tudo isso reforça que a não realização expressa de juízos de relevância gera uma produtividade frustrada, por retroalimentar a litigiosidade. E mais: prova que os critérios da jurisprudência defensiva hoje podem ser vistos

\footnotetext{
40 Apenas a título de curiosidade, é interessante observar que o STF já desconsiderou até mesmo vício de intempestividade para conhecer de agravo regimental, em razão da relevância da matéria. É o que se colhe do seguinte trecho da ementa do seguinte acórdão: “(...) 4. A decisão impugnada foi publicada em 13.3.2007. O agravo foi interposto em 20.3.2007. No dia 19.3.2007, encerrou-se o prazo processual hábil para a interposição do recurso. Agravo regimental intempestivo, porque o recurso foi interposto fora do prazo legal de 5 (cinco) dias. 5. Superacão da questão da intempestividade deste agravo considerando a relevância da tese suscitada pela agravante (...)". (Pleno, Inq 3.105, Rel. Min. Gilmar Mendes, j. 31/10/2007 - destaques acrescentados).

${ }^{41}$ MANCUSO, Rodolfo de Camargo; POLITANO, Vanessa Chacur. Análise crítica do instituto da repercussão geral dentro da atual sistemática processual - necessidade de tomada de ações preventivas. In: FUX, Luiz; FREIRE, Alexandre; DANTAS, Bruno (coords.). Repercussão geral da questão constitucional. Rio de Janeiro: Forense, 2014, p. 599. Em outra obra, porém, o primeiro dos autores acima citados defende que a repercussão geral deve ser aferida antes dos demais requisitos (MANCUSO, Rodolfo de Camargo. Recurso extraordinário e recurso especial. 13. ed. São Paulo: Revista dos Tribunais, 2015, p. 207-210).

$42 \mathrm{O}$ entendimento também era defendido doutrinariamente: “(...) a ausência de requisitos de admissibilidade nos recursos extraordinários que versam temas de repercussão geral não impede o sobrestamento e o futuro juízo de retratação. (...) [Defende-se a] premissa de que a repercussão geral é mais que um requisito de admissibilidade recursal e que provoca a relativização da importância dos demais requisitos frente aos processos múltiplos" (FERRAZ, Taís Schilling. Repercussão geral - muito mais que um pressuposto de admissibilidade. In: PAULSEN, Leandro (coord.). Repercussão geral no recurso extraordinário: estudos em homenagem à Ministra Ellen Gracie. Porto Alegre: Livraria do Advogado, 2011, p. 93 e 95). Em sentido semelhante: FUCK, Luciano Felicio. Repercussão geral: desenvolvimento e desafios. In: FUX, Luiz; FREIRE, Alexandre; DANTAS, Bruno (coords.). Repercussão geral da questão constitucional. Rio de Janeiro: Forense, 2014, p. 390-391.

${ }^{43}$ Nesse sentido, é significativa a imagem de que o STF viria a se tornar um "tribunal de agravos" caso as instâncias de origem permanecessem realizando um juízo defensivo de admissibilidade antes do sobrestamento (FERRAZ, Taís Schilling. Repercussão geral - muito mais que um pressuposto de admissibilidade. In: PAULSEN, Leandro (coord.). Repercussão geral no recurso extraordinário: estudos em homenagem à Ministra Ellen Gracie. Porto Alegre: Livraria do Advogado, 2011, p. 90-91).
} 
como juízos ocultos de irrelevância, justamente por poderem ser superados a partir da relevância reconhecida ao tema.

Reconhecendo os problemas de transparência gerados pela aplicação em massa de óbices técnico-formais de admissibilidade recursal, afirma Luís Roberto Barroso:

“(...) os critérios tradicionais de admissibilidade - que não costumam ser exclusivamente objetivos - também podem, em tese, prestar-se ao papel de rechaçar os casos politicamente difíceis, com a agravante de tal opção restar encoberta. Assim, parece mais democrático que o filtro da Corte seja explícito, até para que fique exposto à crítica pública" ${ }^{44}$.

O exercício oculto de juízos de relevância, especialmente em decisões monocráticas, foi a forma encontrada pelo Tribunal para fazer frente à grande demanda numérica por decisões, assim como para evitar os efeitos colaterais do filtro de teses. Mas trata-se de uma produtividade frustrada, porque retroalimenta e estimula a litigiosidade, num ciclo vicioso em que o número de recursos cresce ainda mais que o de decisões. E parece humanamente impossível exigir coerência de qualquer Tribunal que profira mais de 100 mil decisões por ano, circunstância que potencializa erros de todo tipo. Além de passar a maior parte do tempo consumido pela análise de casos que provavelmente não sobreviveriam a um juízo assumido de relevância - casos que, por isso mesmo, não podem ser considerados relevantes -, essa forma de proceder gera inconsistências, desacreditando a jurisprudência da Corte. Trata-se de um esforço monumental para recusar os casos considerados não relevantes, e que até atinge esse resultado, mas de forma menos transparente, mais trabalhosa e com graves efeitos colaterais, notadamente a retroalimentação da litigiosidade. Nesse sentido:

"Vale observar que o número absurdamente exagerado de pronunciamentos do STF acaba por vulgarizar sua atuação e gera um efeito reflexivo perigoso, pois as instâncias ordinárias deixam de seguir a jurisprudência da Corte ora porque não a conhecem, ora porque ela é contraditória, o que gera mais casos submetidos ao exame do STF, num interminável ciclo vicioso"45.

\section{CONCLUSÃO}

"[O] poder de determinar a sua agenda de julgamentos é inerente ao autogoverno das Cortes Supremas"46. Esse poder, como se procurou demonstrar, vem sendo exercido pelos Ministros do STF de forma solitária, inconsistente e não transparente, por um juízo oculto de relevância veiculado predominantemente em decisões monocráticas. Isso se dá por duas razões básicas: (a) o entendimento de que a ausência de repercussão recai apenas sobre teses jurídicas, e não sobre casos concretos; e (b) o elevado quórum de dois terços para a negativa de repercussão geral. Ao invocar obstáculos técnicos com propósitos defensivos, tais decisões monocráticas equivalem a afirmações de ausência de repercussão geral, embora válidas apenas para o caso concreto e sem observância do quórum constitucional de dois terços.

Isso exige obscurecer a distinção entre, de um lado, o juízo sobre o caráter jurídicoconstitucional da controvérsia, e, de outro, o juízo sobre a sua relevância. A prática atual do STF revela que ambos os juízos, embora formalmente separados, materialmente encontram-se mesclados, de tal modo que os temas considerados relevantes são tidos como constitucionais, e os

${ }^{44}$ BARROSO, Luís Roberto. O controle de constitucionalidade no direito brasileiro. 7. ed. São Paulo: Saraiva, 2016 , p. 140.

${ }^{45}$ DANTAS, Bruno. Repercussão geral. 3. ed. São Paulo: Revista dos Tribunais, 2012, p. 271.

${ }^{46}$ MARINONI, Luiz Guilherme; ARENHART, Sérgio Cruz; MITIDIERO, Daniel. Curso de direito processual civil. Vol. 2. 2. ed. São Paulo: Revista dos Tribunais, 2016, p. 559.

Revista de Direito Brasileira | São Paulo, SP | v. 18 | n. 7 | p. 6 - 29 | Set./Dez. 2017 
irrelevantes como não constitucionais. Ocorre que a relevância de um tema muda com o tempo, o que acaba por revelar a inconsistência desse mecanismo. Há numerosos exemplos de matérias reiteradamente consideradas como não constitucionais pela jurisprudência da Corte, e que passaram a ser tidas como constitucionais, sem qualquer mudança no plano normativo, quando o Tribunal, por alguma razão, passou a reputá-las relevantes.

Trazer à tona o debate sobre inconsistências presentes nas decisões de matérias afetadas à repercussão geral é útil por várias razões. Não é preciso enfatizar a importância de que todo o País conheça as efetivas regras de acesso à sua Suprema Corte, órgão incumbido da guarda da Constituição (CF, art. 102, caput) e responsável pelas decisões de maior relevo e visibilidade. A partir da identificação de inconsistências, pode-se contribuir para a sua prevenção, evitando descrédito sobre a jurisprudência da Corte. Ainda, uma vez constatado que o juízo de irrelevância está sendo exercido sob a forma de milhares de decisões que invocam motivos pretensamente técnicos para negar seguimento a recursos extraordinários, que são descartados quando a Corte passa a ver o tema como importante, pode-se contribuir para que o juízo de relevância seja exercido de forma mais transparente e econômica.

O obscurecimento das efetivas regras de acesso à Suprema Corte já é um mal em si e deve ser desfeito em nome da transparência. Mas não é só: deixar em segundo plano o filtro expresso de relevância tem custado caro ao Tribunal em termos de funcionalidade. Esses problemas podem ser enfrentados a partir das seguintes providências: (a) priorizar o uso de um filtro assumido, colegiado e discricionário de relevância, que se tornaria a ferramenta preferencial do Supremo Tribunal Federal ao exercer a competência recursal extraordinária; e (b) utilizar o filtro formal da repercussão geral não apenas sobre teses, mas também sobre casos concretos. Isso permitiria uma análise bem mais ágil, resultaria numa decisão irrecorrível e numa jurisdição afinal bastante franca, deixando clara a regra básica do jogo: para ser ouvido pelo Supremo Tribunal Federal, o recorrente precisa convencer ao menos quatro Ministros da relevância das questões constitucionais tratadas. Isso é muito mais transparente do que ficar sujeito a um juízo inconsistente sobre o caráter constitucional ou não da controvérsia, que nada mais é do que um filtro de relevância oculto e exercido sem o exigido quórum de dois terços dos Ministros do STF. Tais propostas, que se acredita poderem ser adotadas de lege lata ${ }^{47}$, serão abordadas em futuro trabalho.

\section{REFERÊNCIAS BIBLIOGRÁFICAS}

ALVIM, Arruda. Repercussão geral: impressões e perspectivas. In: FUX, Luiz; FREIRE, Alexandre; DANTAS, Bruno (coords.). Repercussão geral da questão constitucional. Rio de Janeiro: Forense, 2014, p. 107-128.

BARROSO, Luís Roberto. O controle de constitucionalidade no direito brasileiro. 7. ed. São Paulo: Saraiva, 2016.

DANTAS, Bruno. Repercussão geral. 3. ed. São Paulo: Revista dos Tribunais, 2012.

DIDIER JR., Fredie; CUNHA, Leonardo Carneiro da. Curso de direito processual civil. Vol. 3. 13. ed. Salvador: Juspodivm, 2016, p. 372

\footnotetext{
${ }^{47}$ Houve quem, contrariando o otimismo geral com a redução de processos no STF a partir de 2007, já identificasse problemas a partir da volta do aumento dos processos distribuídos em 2012, bem como em razão da subsistência da distribuição de dezenas de milhares de processos por ano à Corte, e formulasse propostas de aperfeiçoamento para a repercussão geral, mas de lege ferenda (RODOVALHO, Thiago. Repercussão geral e o writ of certiorari - uma proposta de lege ferenda. In: FUX, Luiz; FREIRE, Alexandre; DANTAS, Bruno (coords.). Repercussão geral da questão constitucional. Rio de Janeiro: Forense, 2014, p. 641).
} 
FERRAZ, Taís Schilling. Repercussão geral - muito mais que um pressuposto de admissibilidade. In: PAULSEN, Leandro (coord.). Repercussão geral no recurso extraordinário: estudos em homenagem à Ministra Ellen Gracie. Porto Alegre: Livraria do Advogado, 2011, p. 77-107.

A amplitude dos efeitos das decisões sobre questão constitucional de repercussão geral: critérios para aplicação de precedentes no direito brasileiro. Porto Alegre, 2015. Dissertação de mestrado em direito aprovada na PUC/RS. Disponível em: <http://biblioteca.trf4.jus.br/diap/teses/FERRAZ_TA\%C3\%8DS_SCHILLING.pdf>. Acesso em 30 out.2016.

FUCK, Luciano Felicio. Repercussão geral: desenvolvimento e desafios. In: FUX, Luiz; FREIRE, Alexandre; DANTAS, Bruno (coords.). Repercussão geral da questão constitucional. Rio de Janeiro: Forense, 2014, p. 377-401.

GOMES JUNIOR, Luiz Manoel; GAJARDONI, Fernando da Fonseca. Anotações sobre a repercussão geral nos recursos extraordinário e especial. In: FUX, Luiz; FREIRE, Alexandre; DANTAS, Bruno (coords.). Repercussão geral da questão constitucional. Rio de Janeiro: Forense, 2014, p. 443-471.

HARTMANN, Ivan; FERREIRA, Lívia da Silva. Ao relator, tudo: o impacto do aumento do poder do Ministro relator no Supremo. Revista Opinião Jurídica, Fortaleza, ano 13, n. 17, p. 268283.

Disponível

em:

$<$ http://periodicos.unichristus.edu.br/index.php/opiniaojuridica/article/view/266/179>. Acesso em: 30 out.2016.

MANCUSO, Rodolfo de Camargo. Recurso extraordinário e recurso especial. 13. ed. São Paulo: Revista dos Tribunais, 2015.

; POLITANO, Vanessa Chacur. Análise crítica do instituto da repercussão geral dentro da atual sistemática processual - necessidade de tomada de ações preventivas. In: FUX, Luiz; FREIRE, Alexandre; DANTAS, Bruno (coords.). Repercussão geral da questão constitucional. Rio de Janeiro: Forense, 2014, p. 593-613.

MARINONI, Luiz Guilherme; MITIDIERO, Daniel. Repercussão geral no recurso extraordinário. 2. ed. São Paulo: Revista dos Tribunais, 2008.

; ARENHART, Sérgio Cruz; MITIDIERO, Daniel. Curso de direito processual civil. Vol. 2. 2. ed. São Paulo: Revista dos Tribunais, 2016.

MEDINA, Damares. A repercussão geral no Supremo Tribunal Federal. São Paulo: Saraiva, 2016, e-book.

MEDINA, José Miguel Garcia; GUIMARÃES, Rafael de Oliveira; FREIRE, Alexandre. Da repercussão geral: evolução e críticas ao instituto. In: FUX, Luiz; FREIRE, Alexandre; DANTAS, Bruno (coords.). Repercussão geral da questão constitucional. Rio de Janeiro: Forense, 2014, p. 351-376.

MOREIRA, José Carlos Barbosa. Comentários ao Código de Processo Civil. Vol. V, 15. ed. Rio de Janeiro: Forense, 2010. 
OLIVEIRA, Pedro Miranda de. Recurso extraordinário e o requisito da repercussão geral. São Paulo: Revista dos Tribunais, 2013.

RODOVALHO, Thiago. Repercussão geral e o writ of certiorari - uma proposta de lege ferenda. In: FUX, Luiz; FREIRE, Alexandre; DANTAS, Bruno (coords.). Repercussão geral da questão constitucional. Rio de Janeiro: Forense, 2014, p. 633-651.

VERISSIMO, Marcos Paulo. A Constituição de 1988, vinte anos depois: Suprema Corte e ativismo judicial “à brasileira”. In: Revista Direito GV, São Paulo. 4(2), jul.-dez. 2008, p. 407440.

WAMBIER, Teresa Arruda Alvim; WAMBIER, Luiz Rodrigues. Repercussão geral: como transformá-la num instituto adequado à magnitude da missão de uma Corte Superior? In: FUX, Luiz; FREIRE, Alexandre; DANTAS, Bruno (coords.). Repercussão geral da questão constitucional. Rio de Janeiro: Forense, 2014, p. 615-631. 